\title{
Development of a quantitative PCR method for screening ichthyoplankton samples for bigheaded carps
}

\author{
Andrea K. Fritts $(\mathbb{D} \cdot$ Brent C. Knights $(\mathbb{D} \cdot$ James H. Larson $(\mathbb{D} \cdot$ Jon J. Amberg $(\mathbb{D} \cdot$ \\ Christopher M. Merkes (D) Tariq Tajjioui (D) Steven E. Butler (D) \\ Matthew J. Diana - David H. Wahl • Michael J. Weber (1) John D. Waters
}

Received: 21 August 2018/Accepted: 21 November 2018/Published online: 1 December 2018

(C) The Author(s) 2018

\begin{abstract}
Monitoring ichthyoplankton is useful for identifying reproductive fronts and spawning locations of bigheaded carps (Hypophthalmichthys spp.). Unfortunately, sorting and identifying ichthyoplankton to monitor for bigheaded carp reproduction is time consuming and expensive. Traditional methods require frequent egg-larvae sampling, sorting of all samples to obtain presumptively identified bigheaded carp, and genetic validation of presumptively identified eggs. Quantitative PCR (qPCR) has the potential to streamline this process by identifying samples that likely do or do not contain a target species. Our objective was to develop a genetic screening tool using
\end{abstract}

A. K. Fritts $(\varangle) \cdot$ B. C. Knights · J. H. Larson ·

J. J. Amberg · C. M. Merkes · T. Tajjioui

U.S. Geological Survey, Upper Midwest Environmental

Sciences Center, 2630 Fanta Reed Rd., La Crosse,

WI 54603, USA

e-mail: afritts@usgs.gov

S. E. Butler · M. J. Diana · D. H. Wahl

Kaskaskia Biological Station, Illinois Natural History

Survey, 1235 County Road 1000N, Sullivan, IL 61951, USA

\section{J. Weber}

Department of Natural Resource Ecology \& Management, Iowa State University, 207 Science Hall II, Ames,

IA 50011, USA

J. D. Waters

Minnesota Department of Natural Resources, 500

Lafayette Rd., St. Paul, MN 55101, USA
qPCR with the duplex assays SCTM4/5 and BHTM1/2 to prioritize samples that have a higher likelihood of containing bigheaded carp eggs or larvae. We used tandem ichthyoplankton samples collected for monitoring bigheaded carps in the Upper Mississippi, Illinois, and St. Croix rivers to evaluate the effectiveness of qPCR as a screening tool. Samples with $>10,000$ copies of DNA had $100 \%$ occurrence of bigheaded carp eggs or larvae in the traditionally sorted samples, whereas samples with $<10$ copies of DNA had $0 \%$ occurrence of ichthyoplankton from these invasive species. We used a logistic regression model to calculate the probability of finding bigheaded carp eggs or larvae based upon the number of DNA copies; 406 copies corresponded with a 50\% probability of having bigheaded carp ichthyoplankton present in a sample. These data can be used to inform management actions (i.e., control, containment) for these invasive fishes, and this tool could be adapted for monitoring for reproduction of other aquatic invasive species.

Keywords Hypophthalmichthys - Silver carp · Bighead carp · Eggs $\cdot$ Larvae $\cdot$ Genetic screening 


\section{Introduction}

Bighead Carp (Hypophthalmichthys nobilis) and Silver Carp (H. molitrix), collectively referred to as bigheaded carps, are invasive fishes originating from eastern Asia that were introduced to North American waters beginning in the 1970s. Bigheaded carps have become established across large portions of the Mississippi, Missouri, and Ohio River drainages, and are now poised to establish populations in the Great Lakes and the Upper Mississippi River and Ohio River basins. Their high consumptive demand, high reproductive and growth potential, migratory behavior and planktivorous nature make them well suited to compete with native fauna reliant on planktonic food resources, including most larval fishes (Kolar et al. 2005; Fritts et al. 2018). Silver Carp also present a hazard to boaters because of their leaping behavior in response to noise (Vetter et al. 2017). Bigheaded carp spawn pelagically in fast flowing rivers (Kolar et al. 2007) and their eggs must drift for $24-48 \mathrm{~h}$ to successfully hatch, after which the larvae continue to drift until they can occupy suitable nursery habitats (George and Chapman 2013). Managers must know when and where reproduction of bigheaded carp is occurring in invaded systems, especially near the invasion front, to efficiently and effectively contain and control populations.

The traditional method of ichthyoplankton sampling to monitor for bigheaded carp reproduction is tedious, time consuming, and expensive (Kelso et al. 2012; Deters et al. 2013; Hintz et al. 2017). Crews must collect egg and larvae samples with nets during periods of appropriate temperature and discharge. For bigheaded carp in large rivers in the U.S., egg-larvae samples must often be collected weekly from May through October because bigheaded carps can spawn multiple times and are not limited to springtime reproduction (Coulter et al. 2013; Gibson-Reinemer et al. 2017; Larson et al. 2017). The preserved samples are typically sorted visually in the laboratory to remove presumptively identified bigheaded carp eggs and larvae from other species and debris. Debris (i.e., plant matter, suspended soil) in samples collected during high water events can be voluminous relative to the eggs and larvae making sorting samples very time consuming. The time required to process a 'typical' sample from a large river is $2-3 \mathrm{~h}$, and large samples with substantial debris can require up to $20 \mathrm{~h}$ to pick out all eggs and larvae and to identify all ichthyoplankton to an appropriate taxonomic level (Overdyk et al. 2016). This processing leads to a high cost per sample when natural resource agencies conduct identifications, and contracted processing can be prohibitively expensive. Subsampling is a common technique to reduce the processing time per sample (Kelso et al. 2012), but this may not be a desirable option when the targets of the ichthyoplankton monitoring are cryptic or rare species, such as invasive species on the leading edge of an invasion front. Once presumptively identified using traditional microscopy techniques, eggs must also be tested genetically because there is morphological overlap between bigheaded carp and native species in some parts of the Mississippi River basin (George and Chapman 2013; Larson et al. 2016). Management of invasive species is generally time sensitive (Pyšek and Richardson 2010), and these delays in sample processing ultimately lead to delays in information needed for decision making.

Samples with plentiful debris that are difficult and time consuming to process are not exclusive to ichthyoplankton. Microbiologists have faced similar challenges when trying to understand microbial communities in terrestrial soil environments (Boivin-Jahns et al. 1995). The original method of culturing bacteria and identifying them through morphological and biochemical characteristics was very time-consuming and error-prone. Technological advances now allow soil bacteria to be identified by genetic sequence analysis (Liesak and Stackebrandt 1992; Boivin-Jahns et al. 1995; Janssen 2006). These analyses are collectively referred to as DNA barcoding, and are now commonly applied for identification of all living things (Hebert et al. 2003). Further technological advancement and simplification of analyses to look for particular genetic sequences gave rise to the field of environmental DNA (eDNA, Ficetola et al. 2008; Rees et al. 2014). The use of quantitative PCR (qPCR) has allowed for additional insights into diet sources and predation patterns for a broad assortment of organisms, ranging from tunicates to longtail ducks (Weber and Lundgren 2009; Frischer et al. 2014; Fara 2018). Additionally, there has been progress in developing non-destructive genetic methods that can isolate DNA that is sloughed off ichthyoplankton into preservative fluid (i.e., non-denatured ethanol), which allows postprocessing identification of ichthyoplankton using 
traditional morphological or meristic characteristics (Alvarado Bremer et al. 2014; Becker et al. 2015). These technological advances have raised the question whether genetic screening could help streamline the process of traditional ichthyoplankton sampling, particularly when monitoring for the presence and reproduction of invasive species.

Our objective was to develop a genetic screening tool using $\mathrm{qPCR}$ to prioritize samples for processing that have a higher likelihood of containing bigheaded carp eggs or larvae. Quantitative PCR provides information on presence and relative abundance of target species. By providing a means of rapidly prioritizing samples that have the highest likelihood of containing bigheaded carp ichthyoplankton, this screening tool could help save time and money, and provide managers with timely information needed for management of these invasive fishes.

\section{Materials and methods}

\section{Sampling locations}

We sampled ichthyoplankton in three rivers in the midwestern U.S. that cover a gradient of bigheaded carp densities and spawning activity (Fig. 1). Two rivers with relatively high probability of spawning by bigheaded carps (i.e., La Grange through Marseilles pools in the Illinois River and Pool 20 of the Upper Mississippi River) were sampled in May-September 2015 in conjunction with ongoing research and monitoring efforts by the Illinois Natural History Survey (INHS) and Iowa State University (ISU). Samples were also collected in August 2016 by the Minnesota Department of Natural Resources (MN DNR) from the St. Croix River, which forms part of the border between Minnesota and Wisconsin. Occasional pioneer bigheaded carps have been collected in this region but no reproduction has been documented yet (Minnesota Department of Natural Resources 2018).

Egg and larvae collections

Ichthyoplankton sampling targeting bigheaded carp in the three different rivers generally followed similar protocols. Ichthyoplankton samples were collected using a $0.5 \mathrm{~m}$-diameter push net (INHS), $0.75 \mathrm{~m}$ -

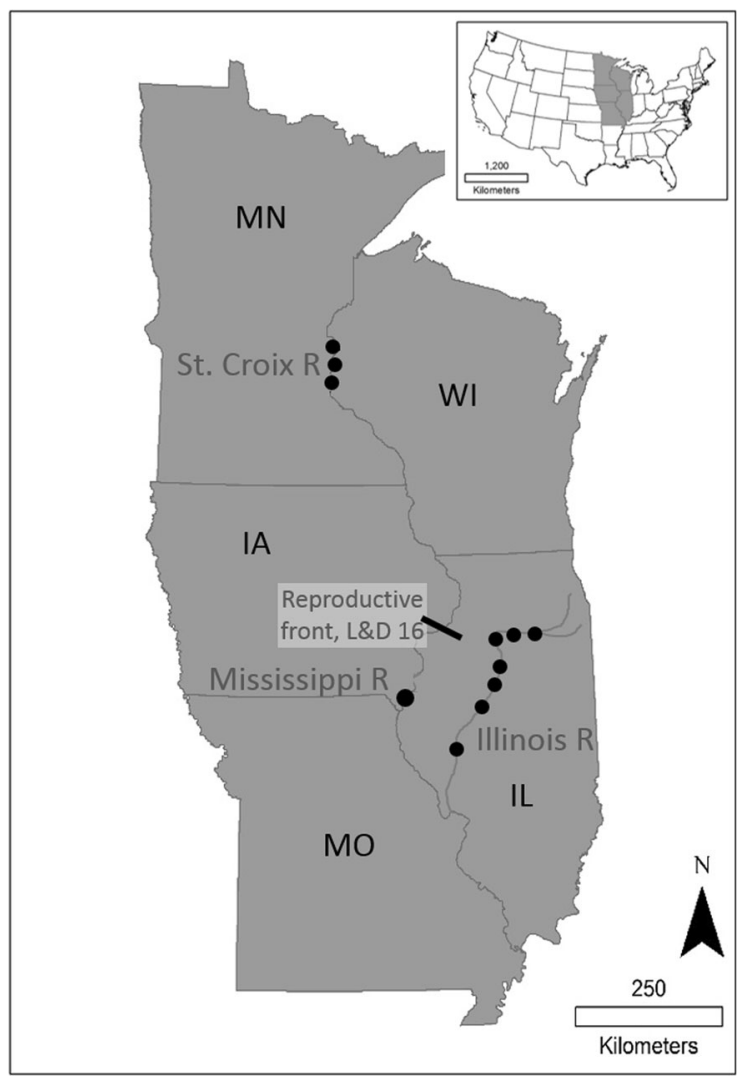

Fig. 1 Ichthyoplankton collection locations in the Upper Mississippi River basin. Samples were collected in the St. Croix River, Pool 20 of Mississippi, and La Grange, Peoria, Starved Rock and Marseilles reaches of the Illinois River. The current bigheaded carp reproductive front is Pool 16 of the Mississippi River

diameter push net (MN DNR), or a 0.5 m-diameter tow net (ISU) with $500 \mu \mathrm{m}$ mesh. To obtain each sample, the net was pushed upstream using an aluminum frame mounted to the front of the boat, or towed upstream on the side of the boat, with the boat speed adjusted to obtain $1.0-1.5 \mathrm{~m} / \mathrm{s}$ water velocity through the net for 4-5 min. Flow was measured using a flow meter (General Oceanics model 2030R) mounted in the center of the net mouth and was used to calculate the volume of water sampled. Fish eggs and larvae were collected in a meshed plankton bucket at the cod end of the net, transferred to sample jars, and preserved in 90-95\% non-denatured ethanol. Nets were flushed without the collection bucket present between sampling sites to reduce the risk of crosscontamination. In the Illinois River, four 
ichthyoplankton samples were collected in addition to the sample collected for DNA screening at each site on each sampling date. The four standard samples were gathered from each side of the river channel, parallel to the bank, at both upstream and downstream locations within each study site. The tandem samples for DNA analysis were collected adjacent to one of these standard samples. In the Mississippi River, two tows were conducted parallel to river flow in the main channel thalweg, with one sample visually identified and one used for DNA screening. In the St. Croix River, three tows were conducted parallel to river flow in the main channel thalweg, with two samples visually identified and one collected for DNA screening.

Traditional sample processing (visual sorting) methods varied among the three agencies. The MN DNR sent samples to a contractor for processing, and INHS and ISU processed samples in their own laboratories to separate fish eggs and larvae from sediment and debris. Fish eggs were separated by size, with all eggs having a membrane diameter larger than $4 \mathrm{~mm}$ (Yi et al. 2006) identified as potential bigheaded carp eggs and retained for further analysis. Bigheaded carp eggs and larvae were identified according to Chapman (2006) and by comparison to a developmental series of Bighead Carp eggs and larvae obtained from a hatchery (Osage Catfisheries, Inc., Osage Beach, Missouri). All eggs and larvae were enumerated and subsamples of presumed bigheaded carp eggs and larvae, along with known Bighead Carp larvae (hatchery source; positive controls) and larvae that were confidently identified as taxa other than bigheaded carp (negative controls) were sent to the US Fish and Wildlife Service (USFWS) Whitney Genetics Lab for molecular confirmation.

\section{DNA processing}

The tandem ichthyoplankton samples, each stored in 500-mL high-density polyethylene bottles, were processed for DNA analysis at the US Geological SurveyUpper Midwest Environmental Sciences Center. To minimize detection of bigheaded carp DNA that was not associated with an egg or larvae (Alvarado Bremer et al. 2014), we exchanged ethanol in each sample by pouring the original ethanol off through a 500- $\mu \mathrm{m}$ nylon mesh filter (Science First; Yulee, FL, USA) placed over the bottle opening to retain the ichthyoplankton and detritus. New molecular grade ethanol was immediately poured back over the sample. Following the ethanol exchange, we gently inverted the ethanol-preserved ichthyoplankton samples five times and placed them on a laboratory bench until the detritus settled. We then removed three $1-\mathrm{mL}$ aliquots of the ethanol (subsamples) from each tow sample. Each ethanol subsample was centrifuged at $5000 \times g$ for $30 \mathrm{~min}$. The supernatant was discarded from the subsample, and then the subsample was placed into an incubator for $15 \mathrm{~min}$ at $60{ }^{\circ} \mathrm{C}$ to evaporate any residual ethanol. DNA from the resulting pellets was extracted using the commercially available gMax mini genomic DNA extraction kit (IBI Scientific; Peosta, IA, USA) in accordance with the manufacturer's guidelines.

qPCR analysis

Each DNA extract was analyzed with qPCR to determine the presence of Silver Carp and/or Bighead Carp DNA. We used the duplex assays SCTM4/5 and BHTM1/2 (Farrington et al. 2015) that are used by the USFWS for their bigheaded carp monitoring program (Woldt et al. 2015). Each DNA extract was analyzed in septet $25-\mu \mathrm{L}$ reactions. Each reaction contained $2 \mu \mathrm{L}$ of extracted sample DNA, $12.5 \mu \mathrm{L}$ Bullseye TaqProbe qPCR 2x Mastermix-Multiplex (Midwest Scientific; Valley Park, MO, USA), $0.5 \mu \mathrm{M}$ each primer, and $0.25 \mu \mathrm{M}$ each probe. A no-template control was included on each plate to test for reagent contamination; no contamination was detected during this study. Inhibition was tested for each sample by spiking 100 copies of our synthetic gBlock (Integrated DNA Technologies; Coralville, IA, USA) DNA standard into three of the seven reactions. This allowed for analysis of each DNA extract in quadruplicate, while testing for inhibition in triplicate; no inhibition was detected during this study. Each plate also contained a standard curve that consisted of two reactions of 10,000 copies, two reactions of 1000 copies, four reactions of 100 copies, and four reactions of 10 copies of gBlock DNA standard. All qPCR assays were conducted on a CFX96 Touch Thermal Cycler (BioRad Laboratories; Hercules, CA, USA) using the following PCR protocol: initial denaturation at $95{ }^{\circ} \mathrm{C}$ for $10 \mathrm{~min}$, followed by 55 cycles of denaturation at $95{ }^{\circ} \mathrm{C}$ for $30 \mathrm{~s}$, annealing temperature of $56^{\circ} \mathrm{C}$ for $30 \mathrm{~s}$, and extension at $68{ }^{\circ} \mathrm{C}$ for $30 \mathrm{~s}$. The number of 
copies of SCTM4/5 and BHTM1/2 for each reaction was determined using the standard curve. We then averaged the copies for the quadruplicate reactions for each subsample.

\section{Statistical analysis}

To assess the association between qPCR copy number and presence of morphologically identified bigheaded carp eggs or larvae in tandem samples, we built a logistic regression model using generalized linear models with binomial distributions and logit links in $\mathrm{R}$ (version 3.3.0; R Core Team 2016). For each of the 3 subsample qPCR measurements from each sample, the number of copies of all four markers was summed, and the triplicate subsample with the maximum sum was used (after $\log (\mathrm{x}+1)$ transformation) as the predictor variable; this subsample represented the greatest amount of potential DNA within the sample. The response variable was the presence or absence of bigheaded carp eggs or larvae in the traditionally sorted samples. We then used this fitted model to calculate the probability of finding bigheaded carp eggs or larvae based upon the number of DNA copies from the qPCR analysis and used the McFadden pseudo- $\mathrm{R}^{2}$ as a measure of predictive power (McFadden 1974). All data are publicly available through ScienceBase (https://doi.org/10.5066/P96BTBUH).

\section{Results}

We analyzed a total of 34 tandem ichthyoplankton samples, which were composed of 12 samples from Pool 20 of the Mississippi River, 18 samples from the Illinois River (La Grange Pool, $\mathrm{n}=7$; Peoria Pool, $\mathrm{n}=5$; Starved Rock Pool, $\mathrm{n}=5$; Marseilles Pool, $\mathrm{n}=1$ ), and 4 samples from the St. Croix River (Table 1). Of the 34 traditionally sorted samples, 12 had bigheaded carp ichthyoplankton present within the sample (5 samples with eggs only, 4 with larvae only, and 3 with both eggs and larvae), and 22 samples had no bigheaded carp eggs or larvae present.

All samples that had a combined total of $>10,000$ DNA copies $(n=7)$ among the four genetic markers had $100 \%$ occurrence of at least one bigheaded carp egg or larvae in the associated tandem sample. The number of egg and larval bigheaded carp present within these seven traditionally sorted samples ranged from 5 to 8608. Samples that had $>1000$ copies $(\mathrm{n}=9)$ had $89 \%$ occurrence, $>100$ copies $(\mathrm{N}=14)$ had $64 \%$ occurrence, and $>10$ copies $(n=24)$ had $50 \%$ occurrence of at least one egg or larvae. For those samples that had between 10 and 10,000 copies of DNA and had bigheaded carp ichthyoplankton present in the traditionally sorted sample, the number of eggs and larvae present in the traditionally sorted samples ranged from 1 to 14 . Samples that had a combined total of $<10$ copies $(n=10)$ had $0 \%$ occurrence of bigheaded carp eggs or larvae in the traditionally sorted sample.

The sample with the smallest number of DNA copies and bigheaded carp presence in the traditionally sorted sample had 18.6 copies of DNA. From the logistic regression equation $\left(\mathrm{R}_{\text {McFadden }}^{2}=0.481\right)$, an $11.3 \%$ probability of bigheaded carp presence is predicted from this number of copies (Fig. 2). The sample with the largest number of DNA copies and no bigheaded carp present in the traditionally sorted sample had 1141 copies of DNA. This equated to an $67 \%$ probability of bigheaded carp presence from the logistic regression prediction (Fig. 2). With 15 copies of DNA, there was a $10 \%$ probability of having a bigheaded carp egg or a larva within the sample, 52 copies corresponded with a $20 \%$ probability, and 406 copies corresponded with a $50 \%$ probability of having bigheaded carp ichthyoplankton present (Table 2). Based upon our 34 samples, 9 contained greater than 406 copies and, of these, 8 contained bigheaded carp eggs or larvae in the traditionally sorted sample, or an $89 \%$ occurrence of bigheaded carp; 25 samples contained fewer than 406 copies and 4 of these contained bigheaded carp ichthyoplankton. Using the $50 \%$ threshold from the logistic regression prediction as a cut-off for identifying samples for traditional processing would have resulted in a $16 \%$ failure to detect bigheaded carp in samples with fewer than 406 copies; the $20 \%$ threshold would have resulted in a $12 \%$ failure to detect, and the $10 \%$ threshold would have had a $0 \%$ failure to detect bigheaded carp with this set of data.

\section{Discussion}

Our results indicate that high and low DNA copy numbers generated from qPCR were useful for identifying samples that have a high or low probability 


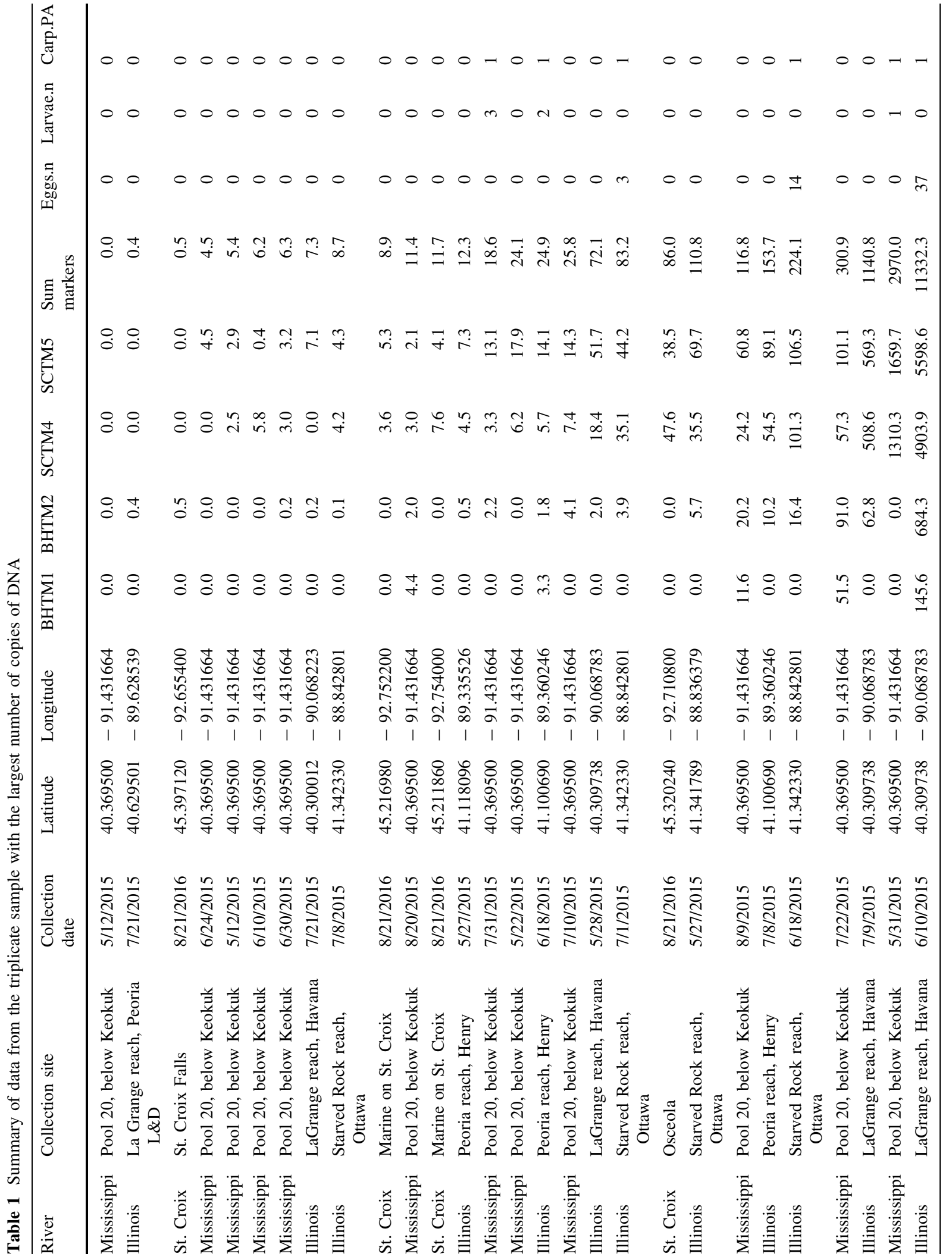




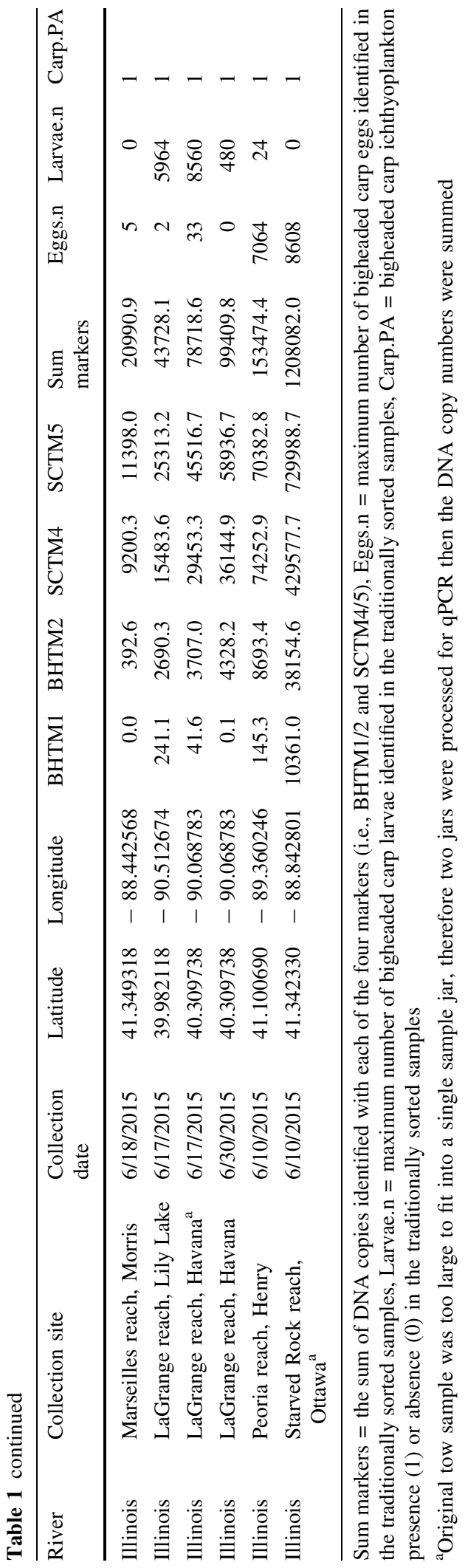

of containing bigheaded carp ichthyoplankton. Samples with $>10,000$ copies of DNA had $100 \%$ occurrence of bigheaded carp eggs and larvae in the tandem traditionally sorted samples, whereas samples with $<10$ copies of DNA had $0 \%$ occurrence of ichthyoplankton from these invasive species. Natural resource agencies and managers could use qPCR as a screening tool to quickly prioritize samples that have the highest likelihood of containing bigheaded carp eggs or larvae. The qPCR technique can be completed expeditiously, with final data available to researchers and managers within 3 days of receiving the samples, given proper coordination and pre-planning with the laboratory (Farrington et al. 2015). The ability to rapidly screen ichthyoplankton samples could enhance management decisions for control efforts for these invasive species as they continue to expand their range in North America.

The logistic regression model performed well at high $(>10,000)$ and low copy numbers for predicting bigheaded carp ichthyoplankton presence or absence, but performance was less consistent at intermediate DNA copy numbers. The DNA copy numbers varied considerably with a small number of eggs or larvae; traditionally sorted samples that had 1 to 14 eggs or larvae present were associated with a wide range of DNA copies (i.e., 18 to 21,000 copies). Additionally, presence of bigheaded carp DNA does not necessarily indicate evidence of carp reproduction. Ichthyoplankton tows often contain a large amount of detritus, debris, and sediment. DNA regularly sticks to these surfaces and can be retained and amplified even when eggs or larvae are absent in sample(s). We attempted to minimize the likelihood of amplifying DNA that had adhered to sample debris by completing an ethanol exchange prior to removing the triplicate ethanol samples for the qPCR analysis (Alvarado Bremer et al. 2014), but this does not guarantee bigheaded carp DNA removal from ichthyoplankton samples.

An additional complicating factor is the presence of Grass Carp (Ctenopharyngodon idella) eggs, which are morphologically indistinguishable from bigheaded carp eggs (Chapman 2006; George et al. 2017). A subset of eggs from all samples with morphologically identified bigheaded carp eggs were processed for genetic verification. All samples with eggs were confirmed to contain at least some bigheaded carp eggs, but without genetically verifying all eggs we 
Fig. 2 Logistic regression curve that predicts the presence of bigheaded carp ichthyoplankton based upon the number of DNA copies within the genetically screened samples. The open circles indicate the associated number of DNA copies for each of the 34 samples. McFadden pseudo$\mathrm{R}^{2}=0.481$

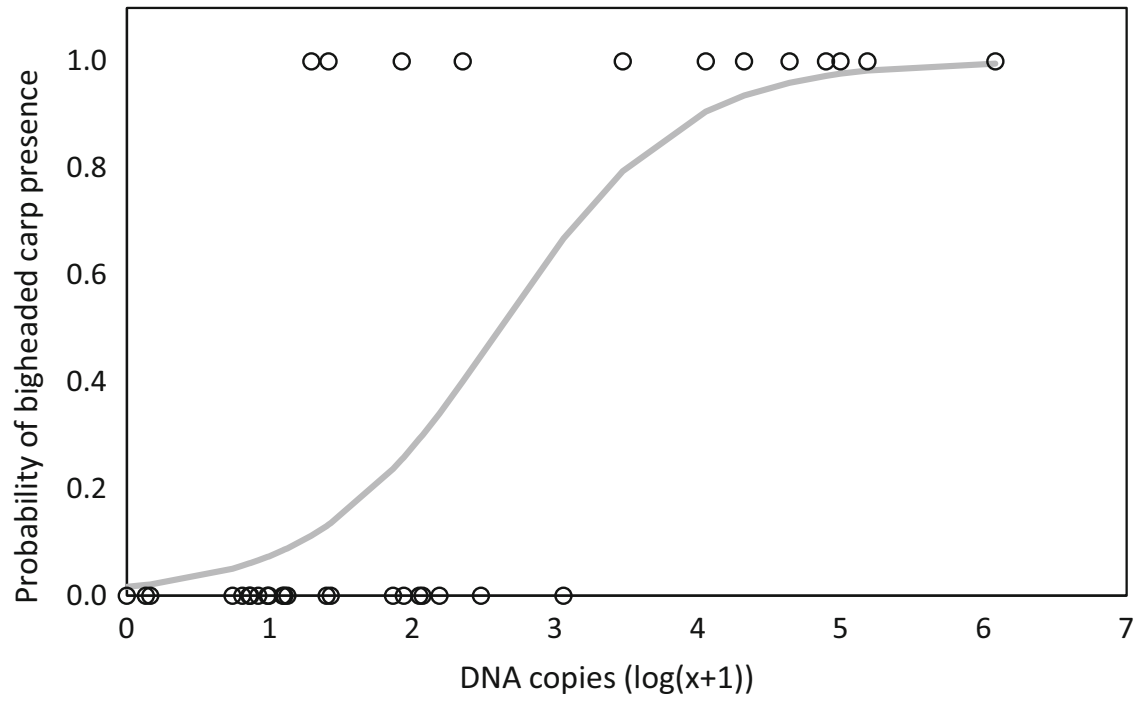

would be unable to state the proportion of eggs that were bigheaded carp versus Grass Carp.

This qPCR screening tool can be used to enhance traditional ichthyoplankton methods (Yoccoz 2012). Quantifying the DNA copies in the ethanol preservation fluid is a non-destructive technique that retains the original eggs or larvae for subsequent morphological evaluation and identification. We opted to quantify the DNA copies from the exchanged ethanol rather than the original ethanol; the original preservation fluid would have a greater likelihood of contamination from adult carp DNA that could originate from mucus or milt. The use of the exchanged ethanol should prove more reliable for detecting DNA that originated from eggs or larvae rather than contamination from adult fishes. Managers can use this screening tool to identify the locations and dates that have the highest probably of bigheaded carp ichthyoplankton (i.e., highest number of DNA copies). These samples can then be prioritized for traditional sorting and subsequent genetic confirmation if bigheaded carp eggs and larvae are found. Successful bigheaded carp spawning has been documented as far upstream as Pool 16 of the Mississippi River (Larson et al. 2017). These screening tools could prove useful for programs that continue to track this and other important invasion fronts.

There has been tremendous progress over the past decade on the development of DNA barcoding and meta-barcoding (Hubert et al. 2008; Briski et al. 2011; Almeida et al. 2018). These genetic techniques seek to identify species based upon standardized gene regions
(Hebert et al. 2003). In the context of ichthyoplankton samples, meta-barcoding has the potential to identify all species within a sample, thereby identifying not only the presence of bigheaded carps but also potentially providing a mechanism to monitor for the effects of bigheaded carps on other pelagic spawning fishes (e.g., Freshwater Drum [Aplodinotus grunniens], Mooneye [Hiodon tergisus]) or zooplankton (e.g., species composition shifts). Even with the advances in meta-barcoding of ichthyoplankton samples, some researchers still support the combined use of the genetic techniques and traditional visual identification (Yoccoz 2012; Overdyk et al. 2016). The cost of DNA sequencing has decreased tremendously in the past two decades (Pennisi 2011), but meta-barcoding is still approximately 10 times more expensive than qPCR and requires 3 to 4 times as much time to process the samples (C. Merkes, U.S. Geological Survey, personal observation). As such, the use of $\mathrm{qPCR}$ as a rapid screening tool for ichthyoplankton samples remains a faster, less expensive option for managers that are tracking bigheaded carp invasion fronts.

We used a combination of two genetic markers each for Silver Carp and Bighead Carp (i.e., SCTM4/5 and BHTM1/2). Since the traditional manual identification of these species is usually to the level of genus (i.e., Hypophthalmichthys spp.) rather than species level, it may prove more efficient and less expensive to use the genus-specific Hypophthalmichthys spp. markers, rather than the specific markers for the two individual species (Farrington et al. 2015; Erickson 
Table 2 Results from the logistic regression analysis using the total number of DNA copies from the triplicate subsample with the greatest amount of DNA from all four bigheaded carp markers (i.e., SCTM4/5 and BHTM1/2)

\begin{tabular}{lllll}
\hline Independent variables & Regression coefficient & SE & $Z$-score & $p$ value $(>|Z|)$ \\
\hline Intercept & -4.089 & 1.253 & -3.265 & 0.001 \\
DNA copies & 1.567 & 0.545 & 2.877 & 0.004 \\
\hline
\end{tabular}

McFadden pseudo- $\mathrm{R}^{2}=0.481$

et al. 2016, 2017). Resource managers are often more focused on identifying the presence of Hypophthalmichthys spp., rather than the specific species, as early life history and management actions are often similar for these two species (Coulter et al. 2018).

Our research has demonstrated the viability of using qPCR as a screening tool for bigheaded carp ichthyoplankton but refinement of the technique is possible. Future application of this method should collect the ethanol samples from the same sample that will be processed using the traditional sorting technique. This would enable analyzing the direct relation between qPCR copy number and the number of eggs or larvae within a sample. Since our qPCR copy numbers were derived from a tandem tow sample and could not be related to a definitive number of eggs or larvae, we opted to conduct our analyses on presence/ absence of bigheaded carp ichthyoplankton, rather than doing a direct correlation of ichthyoplankton abundance versus qPCR copy number. Additional refinements could include quantifying the amount of debris in the tow samples and including this as a covariate in the predictive models.

Future applications of the ichthyoplankton qPCR screening technique include targeting other invasive species such as Black Carp (Mylopharyngodon piceus), Grass Carp, and Northern Snakehead (Channa argus). Black Carp eDNA monitoring is proving more challenging than eDNA monitoring of bigheaded carps because of the tendency of Black Carp to occupy deep benthic habitats in large river systems, which also makes it difficult to capture this species using traditional fisheries techniques (Nico and Jelks 2011). A qPCR screening tool for eggs and larvae of Black Carp might provide insight about the distribution of this species because reproductive strategies are similar to those of bigheaded carp species (Nico et al. 2005). Additionally, the qPCR screening technique could identify the presence of any species with pelagic eggs, including imperiled or endangered species (e.g., Topeka Shiner [Notropis topeka], Rio Grande Silvery Minnow [Hybognathus amarus]) and could therefore be a valuable addition to endangered species recovery programs.

We have shown that qPCR screening tools can allow managers to rapidly identify target species in samples, and thus locations that have a high probability of bigheaded carp reproduction. This technique is relatively inexpensive and returns data in a short period of time, enabling rapid identification of invasion fronts, which could allow managers more time to take action to control these invasive species before their populations begin to grow exponentially.

Acknowledgements Funding sources were the U.S. Geological Survey Ecosystems Mission Area Invasive Species Program, Minnesota Environment and Natural Resource Trust Fund, and the Great Lakes Restoration Initiative (CAFWS-93) with funding administered by the Illinois Department of Natural Resources. We thank the staff of the Kaskaskia, Ridge Lake, and Sam Parr Biological Stations, and graduate students at the University of Iowa, University of Illinois, and Eastern Illinois University for field and laboratory support. We thank Eileen Kirsch and Patrick Kocovsky for their insightful reviews on an earlier draft of this paper. Any use of trade, product, or firm names is for descriptive purposes only and does not imply endorsement by the U.S. Government.

\section{Compliance with ethical standards}

Conflict of interest The authors declare that they have no conflict of interest.

Open Access This article is distributed under the terms of the Creative Commons Attribution 4.0 International License (http:// creativecommons.org/licenses/by/4.0/), which permits unrestricted use, distribution, and reproduction in any medium, provided you give appropriate credit to the original author(s) and the source, provide a link to the Creative Commons license, and indicate if changes were made.

\section{References}

Almeida FS, Frantine-Silva W, Lima SC et al (2018) DNA barcoding as a useful tool for identifying non-native 
species of freshwater ichthyoplankton in the neotropics. Hydrobiologia 817:111-119. https://doi.org/10.1007/ s10750-017-3443-5

Alvarado Bremer JR, Smith BL, Moulton DL et al (2014) Shake and stew: a non-destructive PCR-ready DNA isolation method from a single preserved fish larva. J Fish Biol 84:267-272. https://doi.org/10.1111/jfb.12280

Becker RA, Sales NG, Santos GM et al (2015) DNA barcoding and morphological identification of neotropical ichthyoplankton from the Upper Paraná and São Francisco. J Fish Biol 87:159-168. https://doi.org/10.1111/jfb.12707

Boivin-Jahns V, Bianchi A, Ruimy R et al (1995) Comparison of phenotypical and molecular methods for the identification of bacterial strains isolated from a deep subsurface environment. Appl Environ Microbiol 61:3400-3406

Briski E, Cristescu ME, Bailey SA, MacIsaac HJ (2011) Use of DNA barcoding to detect invertebrate invasive species from diapausing eggs. Biol Invasions 13:1325-1340. https://doi.org/10.1007/s10530-010-9892-7

Chapman DC (2006) Early development of four cyprinids native to the Yangtze River, China. U.S. Geological Survey Data Series 239, p 51

Coulter AA, Keller D, Amberg JJ et al (2013) Phenotypic plasticity in the spawning traits of bigheaded carp ( $\mathrm{Hy}$ pophthalmichthys spp.) in novel ecosystems. Freshw Biol 58:1029-1037. https://doi.org/10.1111/fwb.12106

Coulter AA, Brey MK, Lubejko M et al (2018) Multistate models of bigheaded carps in the Illinois River reveal spatial dynamics of invasive species. Biol Invasions. https://doi.org/10.1007/s10530-018-1772-6

Deters JE, Chapman DC, McElroy B (2013) Location and timing of Asian carp spawning in the Lower Missouri River. Environ Biol Fishes 96:617-629. https://doi.org/10. 1007/s10641-012-0052-z

Erickson RA, Rees CB, Coulter AA et al (2016) Detecting the movement and spawning activity of bigheaded carps with environmental DNA. Mol Ecol Resour 16:957-965. https://doi.org/10.1111/1755-0998.12533

Erickson RA, Merkes CM, Jackson CA et al (2017) Seasonal trends in eDNA detection and occupancy of bigheaded carps. J Great Lakes Res 43:762-770. https://doi.org/10. 1016/j.jglr.2017.06.003

Fara L (2018) Migration patterns, habitat use, prey items, and hunter harvest of long-tailed ducks (Clangula hyemalis) that overwinter on Lake Michigan. Southern Illinois University

Farrington HL, Edwards CE, Guan X et al (2015) Mitochondrial genome sequencing and development of genetic markers for the detection of DNA of invasive bighead and silver carp (Hypophthalmichthys nobilis and H. molitrix) in environmental water samples from the United States. PLoS ONE 10:1-17. https://doi.org/10.1371/journal.pone. 0117803

Ficetola GF, Miaud C, Pompanon F, Taberlet P (2008) Species detection using environmental DNA from water samples. Biol Lett 4:423-425. https://doi.org/10.1098/rsbl.2008. 0118

Frischer ME, Sanchez CA, Walters TL et al (2014) Reliability of qPCR for quantitative gut content estimation in the circumglobally abundant pelagic tunicate Dolioletta gegenbauri (Tunicata, Thaliacea). Food Webs 1:18-24. https://doi.org/10.1016/j.fooweb.2014.11.001

Fritts AK, Knights BC, Lafrancois TD et al (2018) Evaluating potential effects of bigheaded carps on fatty acid profiles of multiple trophic levels in large rivers of the Midwest, USA. Food Webs

George AE, Chapman DC (2013) Aspects of embryonic and larval development in bighead carp Hypophthalmichthys nobilis and silver carp Hypophthalmichthys molitrix. PLoS ONE 8:1-11. https://doi.org/10.1371/journal.pone. 0073829

George AE, Garcia T, Chapman DC (2017) Comparison of size, terminal fall velocity, and density of bighead, silver, and grass carp eggs for use in drift modeling. Trans Am Fish Soc 146:834-843. https://doi.org/10.1097/PCC. 0b013e31823f67d0

Gibson-Reinemer DK, Solomon LE, Pendleton RM et al (2017) Hydrology controls recruitment of two invasive cyprinids: bigheaded carp reproduction in a navigable large river. PeerJ. https://doi.org/10.7717/peerj.3641

Hebert PDN, Cywinska A, Ball SL, DeWaard JR (2003) Biological identifications through DNA barcodes. Proc R Soc B Biol Sci 270:313-321. https://doi.org/10.1098/rspb. 2002.2218

Hintz WD, Glover DC, Szynkowski BC, Garvey JE (2017) Spatiotemporal reproduction and larval habitat associations of nonnative silver carp and bighead carp. Trans Am Fish Soc 146:422-431. https://doi.org/10.1080/00028487. 2017.1281167

Hubert N, Hanner R, Holm E et al (2008) Identifying Canadian freshwater fishes through DNA barcodes. PLoS ONE. https://doi.org/10.1371/journal.pone.0002490

Janssen PH (2006) Identifying the dominant soil bacterial taxa in libraries of $16 \mathrm{~S}$ rRNA and 16S rRNA genes. Appl Environ Microbiol 72:1719-1728. https://doi.org/10.1128/ AEM.72.3.1719

Kelso WE, Kaller MD, Rutherford DA (2012) Collecting, processing, and identification of fish eggs and larvae and zooplankton. In: Zale AV, Parrish DL, Sutton TM (eds) Fisheries techniques, 3rd edn. American Fisheries Society, Bethesda, pp 363-451

Kolar CS, Chapman DC, Courtenay WRJ et al (2005) Asian carps of the genus Hypophthalmichthys (Pisces, Cyprinidae)a biological synopsis and environmental risk assessment. Report to the U.S. Fish and Wildlife Service

Kolar CS, Chapman DC, Courtenay WRJ et al (2007) Bigheaded carps: a biological synopsis and environmental risk assessment, vol Special Pu. American Fisheries Society, Bethesda

Larson JH, McCalla SG, Chapman DC et al (2016) Genetic analysis shows that morphology alone cannot distinguish Asian carp eggs from those of other cyprinid species. North Am J Fish Manag 36:1053-1058. https://doi.org/10.1080/ 02755947.2016.1185057

Larson JH, Knights BC, McCalla SG et al (2017) Evidence of Asian carp spawning upstream of a key choke point in the Mississippi River. North Am J Fish Manag 37:903-919. https://doi.org/10.1080/02755947.2017.1327901

Liesak W, Stackebrandt E (1992) Ocurrence of novel groups of the domain bacteria as revealed by analysis of genetic material isolated from an Australian terrestrial 
environment. J Bacteriol 174:5072-5078. https://doi.org/ 10.1128/JB.174.15.5072-5078.1992

McFadden D (1974) Conditional logit analysis of qualitative choice behavior. In: Zarembka P (ed) Frontiers in econometrics. Academic Press, New York, pp 104-142

Minnesota Department of Natural Resources (2018) Invasive carp sampling report. St. Paul, MN

Nico LG, Jelks HL (2011) The black carp in North America: an update. In: Chapman DC, Hoff MH (eds) Invasive Asian carps in North America. Amercian Fisheries Soceity, Bethesda, pp 89-104

Nico LG, Williams JD, Jelks HL (2005) Black carp biological synopsis and risk assessment of an introduced fish. American Fisheries Society, Bethesda

Overdyk LM, Holm E, Crawford SS, Hanner RH (2016) Increased taxonomic resolution of Laurentian Great Lakes ichthyoplankton through DNA barcoding: a case study comparison against visual identification of larval fishes from Stokes Bay, Lake Huron. J Great Lakes Res 42:812-818. https://doi.org/10.1016/j.jglr.2016.05.011

Pennisi E (2011) Will computers crash genomics? Science 331:666-668

Pyšek P, Richardson DM (2010) Invasive species, environmental change and management, and health. Annu Rev Environ Resour 35:25-55. https://doi.org/10.1146/ annurev-environ-033009-095548

R Core Team (2016) R: A language and environment for statistical computing. R Foundation for Statistical Computing, Vienna, Austria. https://www.R-project.org/
Rees HC, Maddison BC, Middleditch DJ et al (2014) The detection of aquatic animal species using environmental DNA - a review of eDNA as a survey tool in ecology. J Appl Ecol 51:1450-1459. https://doi.org/10.1111/13652664.12306

Vetter BJ, Casper AF, Mensinger AF (2017) Characterization and management implications of silver carp (Hypophthalmichthys molitrix) jumping behavior in response to motorized watercraft. Manag Biol Invasions 8:113-124. https://doi.org/10.3391/mbi.2017.8.1.11

Weber DC, Lundgren JG (2009) Detection of predation using qPCR: effect of prey quantity, elapsed time, chaser diet, and sample preservation on detectable quantity of prey DNA. J Insect Sci 9:41. https://doi.org/10.1673/031.009. 4101

Woldt A, Baerwaldt K, Monroe E et al (2015) Quality assurance project plan-eDNA monitoring of bighead and silver carps. U.S. Fish and Wildlife Service, Bloomington

Yi B, Liang Z, Yu Z et al (2006) A study of the early development of grass carp, black carp, silver carp, and bighead carp in the Yangtze River, China. In: Chapman DC (ed) Early development of four cyprinids native to the Yangtze River, China. U.S. Geological Survey, Data Series 239, pp 15-51

Yoccoz NG (2012) The future of environmental DNA in ecology. Mol Ecol 21:2031-2038. https://doi.org/10.1111/j. 1365-294X.2012.05505.x 